Monstrous Progeny 



\section{Monstrous Progeny}

A History of the Frankenstein Narratives

LESTER D. FRIEDMAN

AND ALLISON B. KAVEY

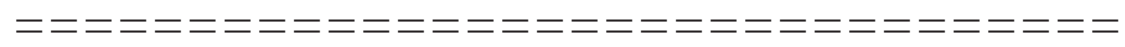

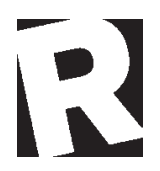

RUTGERS UNIVERSITY PRESS

NEW BRUNSWICK, NEW JERSEY, AND LONDON 


\section{Library of Congress Cataloging-in-Publication Data}

Names: Friedman, Lester D., author. | Kavey, Allison, I977-author.

Title: Monstrous progeny: a history of the Frankenstein narratives /

Lester D. Friedman, Allison B. Kavey.

Description: New Brusnwick, New Jersey: Rutgers University Press, 20I6. |

Includes bibliographical references and index.

Identifiers: LCCN 20I5047575| ISBN 97808I356424I (hardback) |

ISBN 97808I3564234 (pbk.)| ISBN 97808I3564258 (e-book (web pdf))

Subjects: LCSH: Shelley, Mary Wollstonecraft, I797-I85I. Frankenstein. | Shelley, Mary Wollstonecraft, I797-I85I-Adapatations. | Frankenstein, Victor (Fictitious

character)-Miscellanea. | Frankenstein's monster (Fictitious character)— Miscellanea. | Monsters in mass media. | BISAC: PERFORMING ARTS / Film \& Video / History \& Criticism. | LITERARY CRITICISM / Gothic \& Romance. | SOCIAL SCIENCE / Popular Culture. | LITERARY CRITICISM / European / English, Irish, Scottish, Welsh. | LITERARY CRITICISM / Semiotics \& Theory. | SOCIAL SCIENCE / Media Studies. | LITERARY CRITICISM / Science Fiction \& Fantasy.

Classification: LCC PR5397.F73 F785 2016 | DDC 823/.7-dc23

LC record available at http://lccn.loc.gov/2015047575

A British Cataloging-in-Publication record for this book is available from the British Library.

Copyright ( 2016 by Lester D. Friedman and Allison B. Kavey All rights reserved

No part of this book may be reproduced or utilized in any form or by any means, electronic or mechanical, or by any information storage and retrieval system, without written permission from the publisher. Please contact Rutgers University Press, I06 Somerset Street, New Brunswick, NJ 089oI. The only exception to this prohibition is "fair use" as defined by U.S. copyright law.

Visit our website: http://rutgerspress.rutgers.edu

Manufactured in the United States of America 
For Bob Congemi, who inspired me to become a teacher -LDF

For Kraken, my own monster though never my creation $-\mathrm{ABK}$ 

Something was waiting for him in the darkness, a part of himself he couldn't deny.

-Alice Hoffman, The Museum of Extraordinary Things

The world will teach them about monsters soon enough. Let them remember there's always the poker.

-Terry Pratchett, Hogfather 
